\title{
Zn0/CdS Nanocomposite: An Anti-Microbial and Anti-Biofilm Agent
}

\author{
Haribhau Gholap ${ }^{1 *}$, Akash Gholap ${ }^{2}$, Rajendra Patil ${ }^{3 *}$ \\ ${ }^{1}$ Department of Physics, Fergusson College, Pune, India \\ ${ }^{2}$ College of Pharmacy, Mula Education Society Sonai, Ahmednagar, India \\ ${ }^{3}$ Department of Biotechnology, Savitribai Phule Pune University, Pune, India \\ Email:^harishgholap@gmail.com, agholap092@gmail.com, ${ }^{\star}$ rpatil@unipune.ac.in
}

How to cite this paper: Gholap, H., Gholap, A. and Patil, R. (2020) $\mathrm{ZnO} / \mathrm{CdS} \mathrm{Na-}$ nocomposite: An Anti-Microbial and Anti-Biofilm Agent. Advances in Microbiolo$g y, 10,166-179$.

https://doi.org/10.4236/aim.2020.104013

Received: December 24, 2019

Accepted: April 18, 2020

Published: April 21, 2020

Copyright (c) 2020 by author(s) and Scientific Research Publishing Inc. This work is licensed under the Creative Commons Attribution International License (CC BY 4.0).

http://creativecommons.org/licenses/by/4.0/

Open Access

\begin{abstract}
Microbial infectious are becoming a global threat, which is a reason for rise in mortality of human beings. One of the reasons for this mortality has been the drug resistance in microbes. The drug resistance poses a major challenge for effective control of microbial infections, and this threat has prompted us to search for alternative strategy to control the microbial infections. Recently, nanomaterials have emerged as an alternative to conventional platforms because they combine multiple mechanisms of action into one platform due to the distinctive properties of nanosized materials. In the present research we have attempted to synthesize $\mathrm{ZnO} / \mathrm{CdS}$ nanocomposite for its application as an antimicrobial agent. We have characterized the synthesized nanocomposites by X-ray diffraction (XRD), ultraviolet-visible spectroscopy (UV-Vis), photoluminescence spectroscopy (PL), field emission scanning electron microscopy (FESEM) and high-resolution transmission electron microscopy (HRTEM). The nanocomposites have exhibited good antibacterial property against Gram positive and Gram-negative organisms by virtue of the generation of reactive oxygen species (ROS) inside the cells, as reflected by ruptured appearances in the FESEM micrographs. Apart from antimicrobial activity, it also inhibited biofilm formations in Pseudomonas aeruginosa, a causative organism in lung infection and burn associated infections.
\end{abstract}

\section{Keywords}

ZnO/CdS, Antimicrobial, Biofilm, Pseudomonas, Bacillus, Escherichia

\section{Introduction}

Emergence of the antibiotics resistance in pathogens has become a serious health problem which requires an immediate attention. It is known that over $70 \%$ of 
bacterial infections are resistant to one or more of the antibiotics that are generally used to eradicate the infection [1]. There are in general two reasons for antimicrobial resistance; one being the misuse or overuse of antibiotics and second being the ability of microorganisms to form biofilm, a more prominent issue [2]. Biofilms are defined as conglomerations of bacterial cells and it remains with extra polymeric substance (EPS). EPS behaves as diffusion barrier and does not allow an entry of antibiotics inside the biofilm, thereby protecting cells residing inside the biofilm. The consequences of the restricted entry of antibiotics inside biofilm allow cells to grow and proliferate by drawing nutrients from biofilm, eventually emerging as multidrug resistant pathogens [3]. In the medical science, a recent survey shows that up to $60 \%$ of all human infections are owing to the biofilm. Therefore, effective strategies which will eradicate the microorganisms and biofilm have become a need of an hour [4]. In this regard, nanomaterials owing to their nanosized effect (higher surface to volume ratio) showed unique physical and chemical properties different from bulk materials which offer wide applications in various fields. Recently, metal nanoparticles have been reported for antimicrobial and antibiofilm activities [5]. However, semiconductor metal oxide nanostructures are better over all existing nanocomposites owing to very good property of photon absorption as well as efficient transport of photogenerated electron hole charge carriers [6]. Among semiconductor metal oxide, e.g. zinc oxide $(\mathrm{ZnO})$ is tremendously explored due to wide band gap energy of 3.37 $\mathrm{eV}$ and large exciton binding energy (60 meV) [7]. Another reason for wide applications of $\mathrm{ZnO}$ nanoparticles in antimicrobial and antimicrobial research has been its constant photo-catalytical activities under harsh processing conditions [8]. Upon illumination, $\mathrm{ZnO}$ nanoparticles generate the electron hole pairs, and produce reactive oxygen species (ROS), which oxidizes organic matter and, thus, imparts biocidal property to $\mathrm{ZnO}$ [9]. However, $\mathrm{ZnO}$ nanoparticles are having a very low efficiency for the separation of electron hole pairs due to fast recombination of charge carriers [10]; therefore, efforts have been made to suppression of the recombination of photogenerated electron-hole pairs in $\mathrm{ZnO}$ nanoparticles. In this regard, $\mathrm{ZnO}$ nanoparticles have been doped or conjugated with other nanoparticles such as $\mathrm{ZnO} / \mathrm{CdTe}$ for antimicrobial applications [11], $\mathrm{ZnO} / \mathrm{CdSe}$ for photoelectrode for splitting water [12], $\mathrm{ZnO} / \mathrm{CdS}$ for enhanced field emission behavior [13], ZnO/CdS for enhanced photocatalytic activity [14], $\mathrm{ZnO} / \mathrm{CdS}$ for antibacterial activity [15], $\mathrm{ZnO} / \mathrm{CdS}$ for enhanced photocatalytic $\mathrm{H}_{2}$ evolution [16], and $\mathrm{ZnO} / \mathrm{CdS}$ nanocomposite for Solar cell [17]. Herein, we have attempted to enhance the photocatalytic efficiency $\mathrm{ZnO}$ nanoparticles by synthesizing a composite with CdS nanoparticles, and further evaluated its antimicrobial and antibiofilm.

\section{Materials and Methods}

\subsection{Chemicals}

The as-synthesized $\mathrm{ZnO} / \mathrm{CdS}$ nanocomposites were synthesized by using analyt- 
ical grade zinc nitrate hexahydrate $\left(\mathrm{Zn}\left(\mathrm{NO}_{3}\right)_{2} \cdot 6 \mathrm{H}_{2} \mathrm{O}, 98 \%\right)$, potassium hydroxide (KOH, 99\%), cadmium nitrate $\left(\mathrm{Cd}\left(\mathrm{NO}_{3}\right)_{2}\right)$, thiourea $\left(\mathrm{SC}\left(\mathrm{NH}_{2}\right)_{2}\right)$, polyvinyl pyrrolidone (PVP), without further purifications.

\subsection{Synthesis of ZnO Nanostructure}

In the typical of $\mathrm{ZnO}$ nanostructures, $1 \mathrm{mmol}$ of $\mathrm{Zn}\left(\mathrm{NO}_{3}\right)_{2} \cdot 6 \mathrm{H}_{2} \mathrm{O}$ and $5 \mathrm{mmol}$ of $\mathrm{KOH}$ were dissolved in $100 \mathrm{~mL}$ aqueous solution. Then mixture immediately transferred into a Teflon-lined stainless-steel autoclave. The hydrothermal synthesis was carried out at $120^{\circ} \mathrm{C}$ etc. for $2 \mathrm{~h}$ duration. After completion of the synthesis duration, product washed with distilled water and dried in oven at $70^{\circ} \mathrm{C}$.

\subsection{Synthesis of $\mathrm{ZnO} 0$-CdS Heterostructures}

In addition to $\mathrm{ZnO}$ synthesis process $0.63 \mathrm{mM} \mathrm{Cd}\left(\mathrm{NO}_{3}\right)_{2}, 1.9 \mathrm{mM} \mathrm{PVP}$ and $0.0150 \mathrm{~g} \mathrm{SC}\left(\mathrm{NH}_{2}\right)_{2}$ were added. Then mixture immediately transferred into a Teflon-lined stainless-steel autoclave $(200 \mathrm{~mL})$. The hydrothermal synthesis was carried out at temperatures $120^{\circ} \mathrm{C}$ etc. for $2 \mathrm{~h}$ duration. After completion of the synthesis duration, product washed with distilled water and dried in oven at $70^{\circ} \mathrm{C}$.

\subsection{Antimicrobial Study}

Antimicrobial study was performed by measuring growth inhibition ability of $\mathrm{ZnO}$ nanostructures and $\mathrm{ZnO} / \mathrm{CdS}$ nanocomposite by using model organisms such as Bacillus subtilis NCIM 2063 and Escherichia coli NCIM 2931 via colony count method under 60 - 100 Lux intensity of visible light. ZnO nanostructures and $\mathrm{ZnO} / \mathrm{CdS}$ nanocomposite in the concentration range of 0 to $20 \mu \mathrm{g} / \mathrm{mL}$ each were added to Muller Hinton broth, and each one separately inoculated with $B$. subtilis and $E$. coli (final cell density of $1 \times 10^{6}$ colony forming units per mililitre $(\mathrm{CFU} / \mathrm{mL})$ ) and incubated at $37^{\circ} \mathrm{C}$ for $15 \mathrm{~h}$. After $15 \mathrm{~h}$, viable numbers of cells were recorded as $\mathrm{CFU} / \mathrm{mL}$ in comparison to control (without nanomaterials). The data were confirmed as survival rates (CFU/mL), (100\% survival in control). Morphological alterations on the surface of microorganisms were observed under FESEM. In short, the cells of B. subtilils and E. coli were grown to mid log phase (approximately $1 \times 10^{7}$ cells $/ \mathrm{mL}$ ) and treated with respective MIC concentration of $\mathrm{ZnO}$ and $\mathrm{ZnO} / \mathrm{CdS}$ nanocomposite for $3 \mathrm{~h}$ at $37^{\circ} \mathrm{C}$ and 200 r.p.m. The cells were collected by centrifugation at $11,000 \mathrm{~g}$ for $15 \mathrm{~min}$ at $4^{\circ} \mathrm{C}$. The pellets were then washed 3 times with $0.1 \mathrm{M}$ phosphate buffer of $\mathrm{pH} 7.4$ and fixed in $2.5 \%$ glutaraldehyde at $4^{\circ} \mathrm{C}$ for $4 \mathrm{~h}$. After rinsing 2 - 3 times with buffer, the pellets were dehydrated in ethanol serials (10\% - 100\%, 20 min per step), and then dried in air. Finally, the images were seen under FESEM [18].

\subsection{Antibiofilm Study}

Antibiofilm study of $\mathrm{ZnO}$ and $\mathrm{ZnO} / \mathrm{CdS}$ nanocomposite was studied in Pseu- 
domonas aeruginosa at 60 - 100 Lux intensity of visible light. It was carried out by using crystal violet retention assay because crystal violet has an affinity towards polysaccharides of biofilm. In summary, the $P$. aeruginosa was grown overnight in Luria Bertaini (LB) medium at $37^{\circ} \mathrm{C}$ with agitation. Later, the culture was diluted with LB medium (OD600-0.02), and $50 \mu \mathrm{L}$ of the diluted culture was added to $950 \mu \mathrm{L}$ of LB medium and allowed to form biofilm. After formation of biofilm on polystyrene plastic surfaces, the planktonic cells (cells which are suspended in the medium) were replaced with fresh medium supplemented with 0 - $125 \mu \mathrm{g} / \mathrm{mL} \mathrm{ZnO}$ and $\mathrm{ZnO} / \mathrm{CdS}$ nanocomposite, separately, and incubated statically for $20 \mathrm{~h}$ at $37^{\circ} \mathrm{C}$. After incubation, planktonic bacteria were removed, and the biofilms were washed 2 - 3 times with phosphate buffered saline buffer. Washed biofilms were fixed with $1 \mathrm{~mL}$ of methanol. After $15 \mathrm{~min}$, the methanol was removed, and the plates were dried at room temperature. Crystal violet $(0.1 \%$ in water) was then added to each well $(1 \mathrm{~mL} /$ well $)$, and the plates were incubated for $15 \mathrm{~min}$ at room temperature. Crystal violet was then removed, and stained biofilms were washed three times with $1 \mathrm{~mL}$ of water. Acetic acid (33\% in water) was added to the stained biofilms in order to solubilize the crystal violet, and the absorbance of the solution was read at $590 \mathrm{~nm}$ with a spectroscopy (Schimadzu, Japan) [18].

\section{Result \& Discussion}

\subsection{X-Ray Diffraction (XRD)}

A typical XRD patterns of $\mathrm{ZnO}$ (red coloured) \& $\mathrm{ZnO} / \mathrm{CdS}$ (black colored) nanocomposites (Figure 1(a) and Figure 1(b)), show a set of well-defined crystal planes are indexed to the hexagonal wurtzite phase, with lattice constants, $\mathrm{a}=$ $0.325 \mathrm{~nm}$ and $\mathrm{b}=0.520 \mathrm{~nm}$ (JCPDS: $36-1451$ ) \& $\mathrm{ZnO} / \mathrm{CdS}$ nanocomposite exhibits a set of well-defined crystal planes are indexed to the hexagonal wurtzite phase of $\mathrm{ZnO}(\mathrm{a}=0.3249 \mathrm{~nm}$ and $\mathrm{c}=0.5206 \mathrm{~nm}$; JCPDS File: 036-1451) and observation of the diffraction spectrum shows the occurrence of some low intensity crystal planes, which are indexed to the cubic phase of CdS (JCPDS File: 080-0019). The crystal planes correspond to the (111), (220) and (311) of cubic CdS (shown in the inset). CdS nanoparticle has a higher full width half maxima (FWHM) of the crystal planes due to smaller nanoparticle size compare to $\mathrm{ZnO}$. No crystal planes corresponding to other phases or impurities were observed. Thus, the XRD results evidently show the formation of $\mathrm{ZnO} / \mathrm{CdS}$ nanocomposite.

\subsection{Optical Properties}

The optical properties of $\mathrm{ZnO}$ and $\mathrm{ZnO} / \mathrm{CdS}$ nanocomposite samples were studies by UV-visible diffused reflectance (UV-Vis-DRS) and photoluminescence spectroscopy (PL) at taken at room temperature. The UV-visible diffused reflectance (UV-Vis-DRS) of $\mathrm{ZnO} / \mathrm{CdS}$ nanocomposite was shown in Figure 1 (d). The spectrum of only $\mathrm{ZnO}$ nanostructure which illustrates the sharp absorption band 

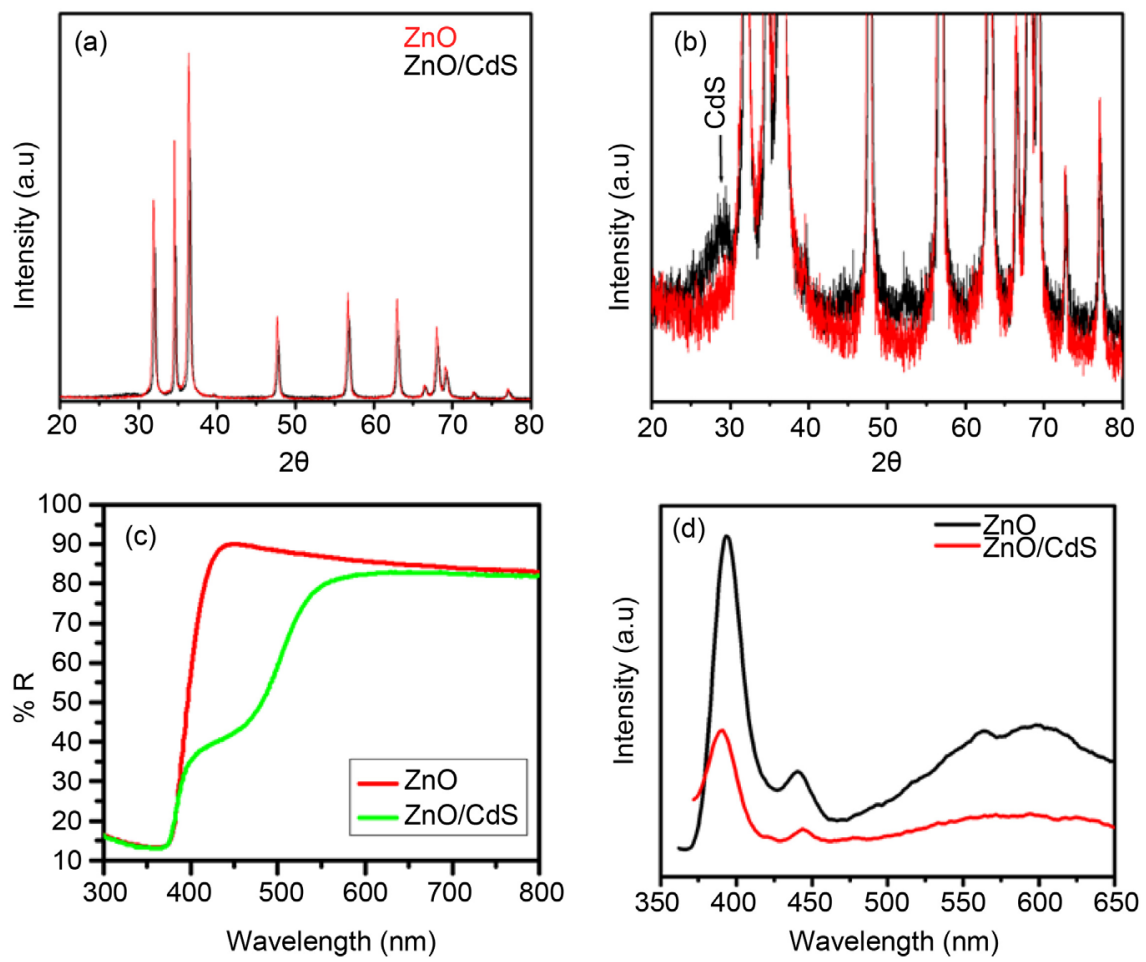

Figure 1. (a) $\mathrm{XRD}$ of $\mathrm{ZnO}$ and $\mathrm{ZnO}-\mathrm{CdS}$ nanocomposite; (b) (Inset) $\mathrm{XRD}$ of $\mathrm{ZnO}$ and $\mathrm{ZnO}-\mathrm{CdS}$ nanocomposite, (c) UV-Vis-DRS spectra of $\mathrm{ZnO}$ and $\mathrm{ZnO}-\mathrm{CdS}$ nanocomposite; (d) PL spectra of $\mathrm{ZnO}$ and $\mathrm{ZnO}-\mathrm{CdS}$ nanocomposites.

at $385 \mathrm{~nm}(3.22 \mathrm{eV})$ was known to originate from the band-edge absorption and with no apparent absorption in the visible region. In case of $\mathrm{ZnO} / \mathrm{CdS}$ nanocomposite, the absorption spectra in which the band edges at $\sim 385(3.22 \mathrm{eV})$ and $520 \mathrm{~nm}(2.38 \mathrm{eV})$ are corresponds to the $\mathrm{ZnO}$ and $\mathrm{CdS}$, respectively (Figure $1(c)$ ). The two band edges feature in the typical spectra clearly shows the formations of nanocomposite between the UV region band $(\mathrm{ZnO})$ and visible region (CdS).

\subsection{Photoluminescence Spectroscopy (PL)}

In order to shows the influence of CdS nanoparticles on the electronic properties of $\mathrm{ZnO}$, the PL spectra of the $\mathrm{ZnO}$ in the range of $350-650 \mathrm{~nm}$ at room temperature is shown in Figure 1(c). In the case of pure $\mathrm{ZnO}$, a narrow $\mathrm{UV}$ band emission at $393 \mathrm{~nm}$ was observed, which can be assigned to exciton recombination, a strong blue emission at $\sim 400-450 \mathrm{~nm}$, and a broad green band at about $554 \mathrm{~nm}$ as well as a strong emission at $596 \mathrm{~nm}$ in the yellow region, which can be attributed to intrinsic defects in $\mathrm{ZnO}$ as oxygen interstitials dominates the PL spectrum [19]. The intensity of the characteristic peaks in the PL spectrum of $\mathrm{ZnO} / \mathrm{CdS}$ nanocomposite was smaller than that for the $\mathrm{ZnO}$. The observed decrease in the overall intensity of the PL spectrum is attributed to the decrease in the oxygen vacancies [20]. We also assume that flakes like structure on the surface would possess more defects due to the faster one-dimensional (1D) crystal 
growth. The PL emission band shift in the visible region $\sim 520 \mathrm{~nm}$ of spectrum and could be attributed to the interaction between the two semiconductors of $\mathrm{ZnO}$ and CdS. The change in the wavelength can be ascribed to the change in oxygen vacancy centers around CdS. The broad emission peak centered at $\sim 520$ $\mathrm{nm}$ (which corresponds to the green-yellow emission) can be ascribed to the shallow defect transition of CdS nanoparticles. The decrease in the hydroxyl species on the $\mathrm{ZnO}$ surface is due to the presence of the $\mathrm{CdS}$ nanoparticles in the nanocomposite [21] [22]. The conduction band edge of CdS is above to that of the $\mathrm{ZnO}$. When the visible light incident on $\mathrm{ZnO} / \mathrm{CdS}$ nanocomposite the excited electron-hole pairs are generated. Owing to the explicit nature of the band alignment at the interface of $\mathrm{ZnO} / \mathrm{CdS}$ nanocomposite, the generated electrons are moving to the conduction band of $\mathrm{ZnO}$, at the same time as the holes with the valence band of the CdS. These alienated electrons and holes have a drastically improved recombination lifetime of electron-hole pairs, and so available for redox reactions, and may play a vital role in the inhibition of growth/biofilm by the nanocomposite, as discussed further in the text.

\subsection{Morphology}

The morphology of $\mathrm{ZnO}$ nanoparticles was studies by FESEM (Figures 2(a)-(c)). It's well-defined flakes-like three-dimension (3D) microstructures with diameters in the range of $1-2 \mu \mathrm{m}$. A close-up view of the nanosheets-built flakes-like microstructures reveals that the nanosheets are about $\sim 10 \mathrm{~nm}$ in thickness, and they alternately connect with each other to form a network-like surface of the "flakes." Similarly, in case $\mathrm{ZnO} / \mathrm{CdS}$ heterostructures (Figures 2(d)-(f)), the CdS nanoparticles were seen on the surface of flake like $\mathrm{ZnO}$ with
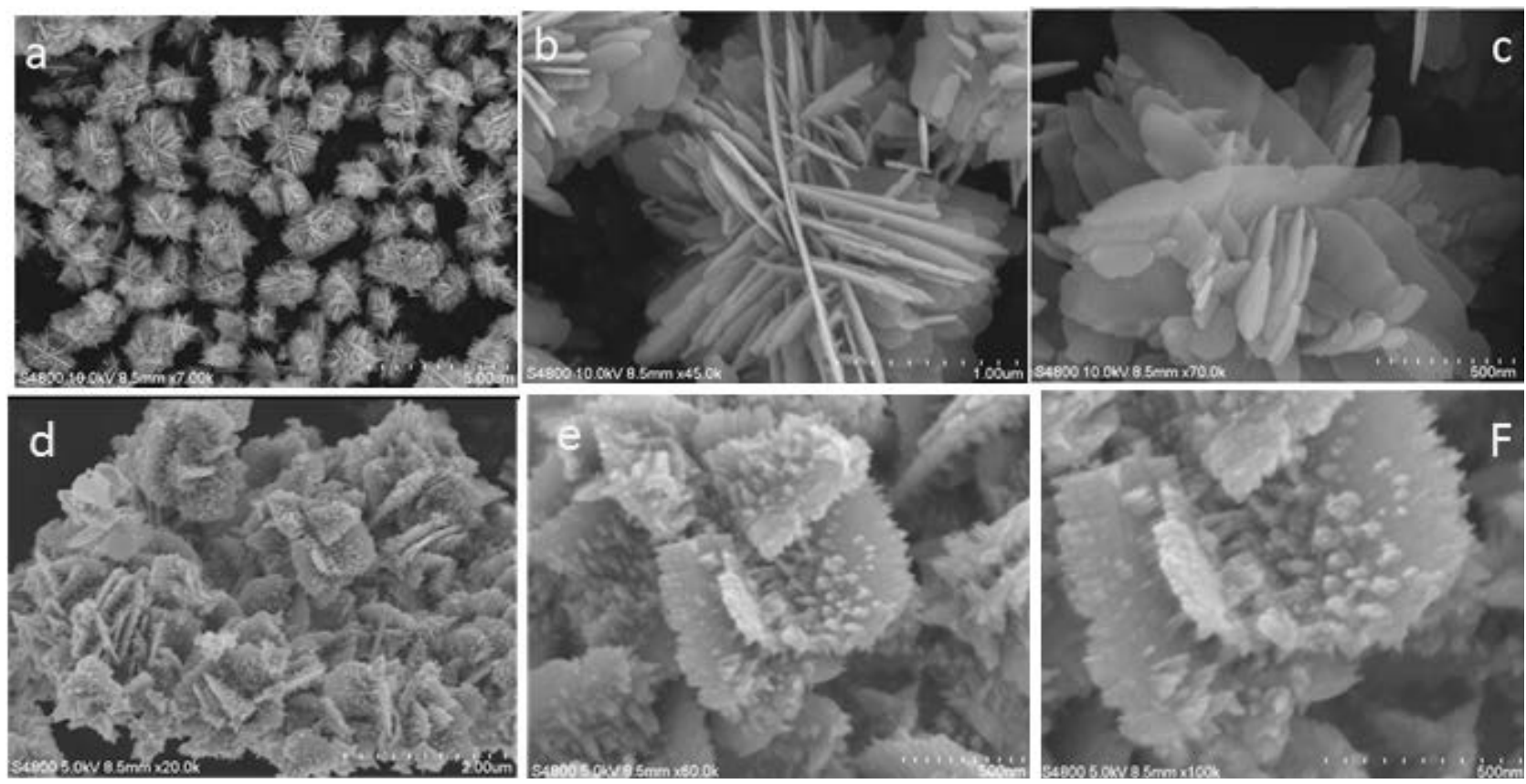

Figure 2. FESEM micrographs of $\mathrm{ZnO}((\mathrm{a})-(\mathrm{c}))$ and $\mathrm{ZnO} / \mathrm{CdS}$ nanocomposite ((d)-(f)). 
average size $\sim 15$ - $20 \mathrm{~nm}$. Further the morphological and structural analysis of $\mathrm{ZnO}$ and $\mathrm{ZnO} / \mathrm{CdS}$ was carried out using TEM and HRTEM (Figure 2 and Figure 3). Flakes like $\mathrm{ZnO}$ microstructure were observed under TEM, confirming the hierarchical 3D structure with diameter around $1-2 \mu \mathrm{m}$, constructed by numerous nanosheets which have uniform thickness of $\sim 10 \mathrm{~nm}$ (Figures 2(a)-(c)) and HRTEM image shows typical well defined lattice fringes width $0.26 \mathrm{~nm}$ which corresponding to the growth orientation along (002) plane (Figures 3(a)-(c)). Similarly, in case of $\mathrm{ZnO} / \mathrm{CdS}$ nanocomposite, TEM images show that the of $\mathrm{CdS}$ nanoparticles on the flakes of $\mathrm{ZnO}$ (Figures 2(d)-(f)) (a magnified image). Magnified view shows a single crystalline nature of $\mathrm{ZnO}$ and $\mathrm{CdS}$ which is marked by with red color circles. The average size of CdS nanoparticles were about $\sim 8-10 \mathrm{~nm}$. The appearance of rings along with spots in the SAED pattern of the $\mathrm{ZnO} / \mathrm{CdS}$ may be due to orientation disorder between the $\mathrm{ZnO}$ nanoflakes and the CdS nanoparticles (Figure 3(f)).

\subsection{Antibacterial}

The effect of different concentrations of $\mathrm{ZnO}$ and $\mathrm{ZnO} / \mathrm{CdS}$ nanocomposites on the growth of B. subtilis and E. coli was shown in Figure 4. When the cells of the model organisms were subjected to increasing concentrations of $\mathrm{ZnO}$ and $\mathrm{ZnO} / \mathrm{CdS}$ nanocomposite, the viability of cells decreased. The initial number of
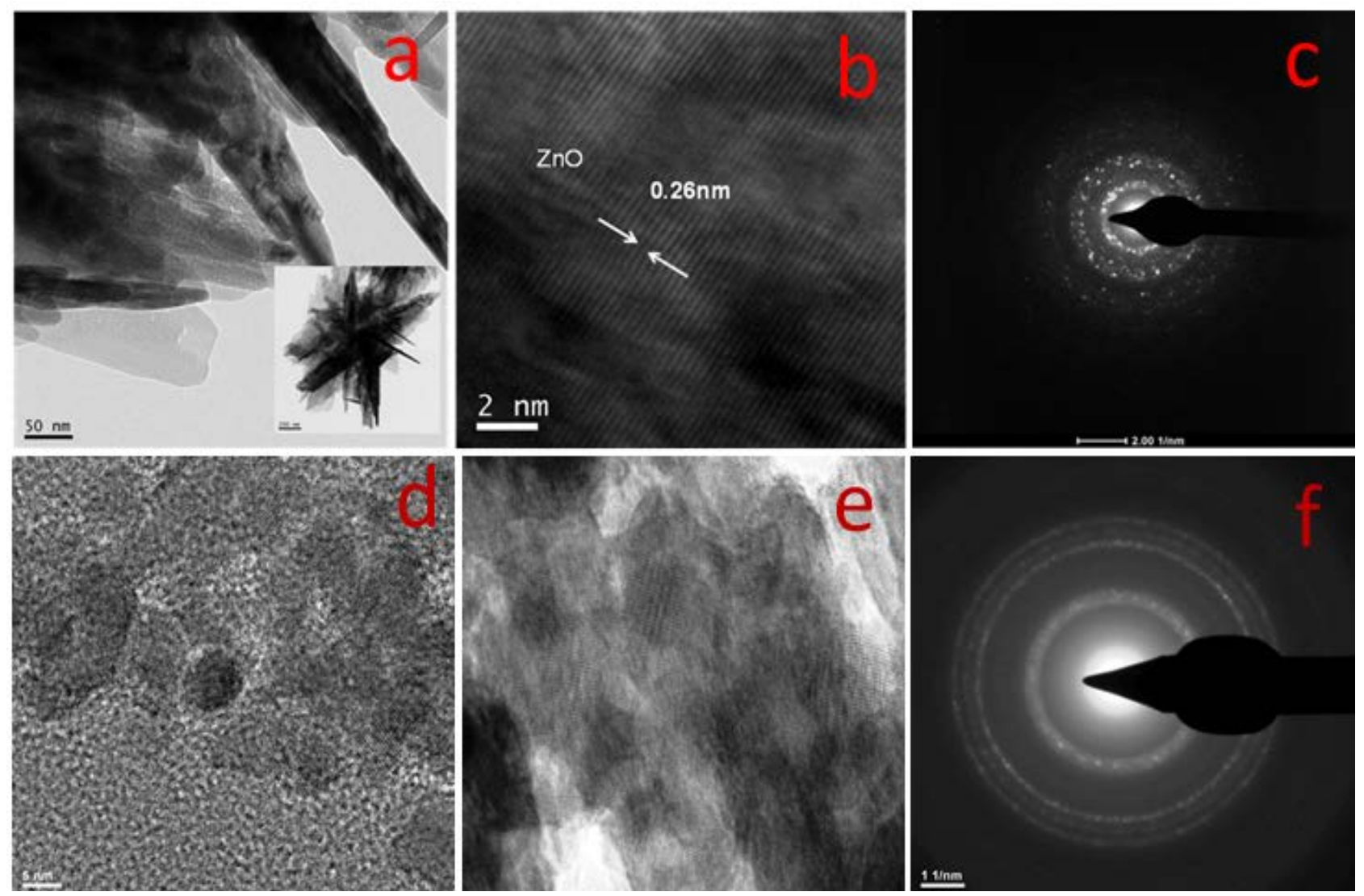

Figure 3. HRTEM micrographs of $\mathrm{ZnO}((\mathrm{a})$ and (b)) and $\mathrm{ZnO} / \mathrm{CdS}((\mathrm{d})-(\mathrm{f}))$. 

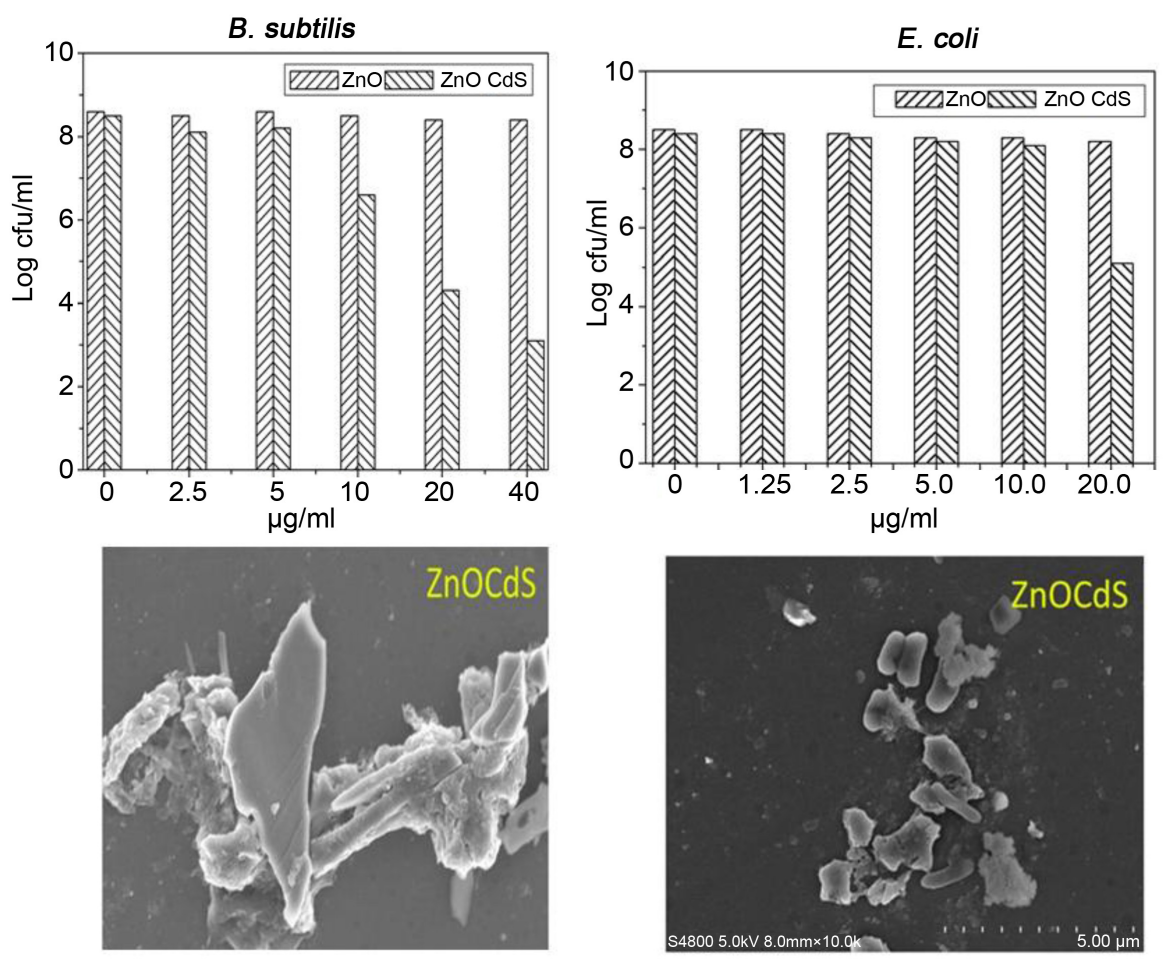

Figure 4. Antibacterial activities of $\mathrm{ZnO}$ and $\mathrm{ZnO} / \mathrm{CdS}$ on B. subtilis and E. coli (upper panel) and SEM micrographs of $B$. subtilis (left) and $E$. coli (right) in presence of $\mathrm{ZnO} / \mathrm{CdS}$.

viable number bacterial cells, approximately $6 \mathrm{Log} \mathrm{CFU} / \mathrm{mL}$ increased to approximately $9 \mathrm{Log} \mathrm{CFU} / \mathrm{mL}$ at $0 \mu \mathrm{g} / \mathrm{mL} \mathrm{ZnO}$ and $\mathrm{ZnO} / \mathrm{CdS}$ nanocomposite after $18 \mathrm{hrs}$ of incubation. This represents a $100 \%$ growth (Figure 4). Upon increasing concentration of $\mathrm{ZnO}$ and $\mathrm{ZnO} / \mathrm{CdS}$ nanocomposites, it was observed that whereas $\mathrm{ZnO}$ had a little effect on the growth of microorganisms, $\mathrm{ZnO} / \mathrm{CdS}$ has decreased the growth by 1 to $3 \mathrm{Log} \mathrm{CFU} / \mathrm{mL}$. The concentration of $\mathrm{ZnO} / \mathrm{CdS}$ nanocomposites required to reduce $3 \mathrm{Log} \mathrm{CFU} / \mathrm{mL}$ in B. subtilis and E. coli was 20 $\mu \mathrm{g} / \mathrm{mL}$. It is interesting to note that the $\mathrm{ZnO} / \mathrm{CdS}$ nanocomposites have a dissimilatory action on B. subtilis and E. coli, it is more prominent on B. subtilis, due to difference in the cellular structures. E. coli possesses an extra outermost layer made up of lipopolysaccharides, therefore, acts as a permeable barrier and restricted the damages cause to the cytoplasmic membrane. Our findings agreed with previous reports [23] [24]. The other reason for the predominance action of $\mathrm{ZnO} / \mathrm{CdS}$ nanocomposite on $E$. coli is due the polarity of cell membrane of $E$. coli. Microorganism E. coli has fewer negative charges than B. subtilis, and therefore allows greater penetration of free radical such as hydroxyl radicals $(\cdot \mathrm{OH})$, superoxide peroxide anions $\left(\mathrm{O}_{2}^{--}\right)$in $B$. subtilis and a preferred action on B. subtilis [23].

Several suggestions have been proposed to explain the mechanism of antimicrobial action of $\mathrm{ZnO}$ nanocomposites. The release of $\mathrm{Zn}^{2+}$ has been suggested as one of the reasons for the antimicrobial activity [24]. According to this theory, 
the toxicity of $\mathrm{ZnO}$ nanocomposite arose due to the dissolution of $\mathrm{Zn}^{2+}$ into the medium containing microorganisms. However, in our study, the $\mathrm{Zn}^{2+}$ leached into the medium were too less to inhibit the growth of microorganisms. Hence, we rule out this hypothesis. Oxidative stress mediated antimicrobial mechanisms of $\mathrm{ZnO}$ nanocomposites have also being suggested. According to this theory, the inactivation of bacteria by $\mathrm{ZnO}$ nanocomposites involves $\mathrm{ZnO}$-mediated change in the permeability of membrane allowing the internalization of nanocomposites and induces the oxidative stress. However, when we assayed the molecular marker enzymes of oxidative stress viz., Catalase and Superoxide dismutase, we found that the expression levels of these two enzymes were like control. Secondly, the pore size in the cells wall of bacteria under study were small, approximately, 4 to $10 \mathrm{~nm}$, so it was not practical possible to $\mathrm{ZnO} / \mathrm{CdS}$ nanocomposite to enter the cell through cell membrane [25].

When the nanostructures interact with the cellular membrane of microorganisms in presence of sunlight, the electron and hole generated in which hole remains in the valence band and electron move towards the conduction band. Hence, while, electrons in the conduction band shows higher reducing power, where holes in the valence band shown higher oxidizing power [26]. As a result, when molecular oxygen reacts with electron, $\mathrm{O}_{2}^{-}$is produced in the conduction band through a reductive process. In the valence band, the hole abstracted electrons from the water and/or hydroxyl ions to generate ${ }^{\circ} \mathrm{OH}$ through an oxidative process. Singlet oxygen (1O2) was mostly produced indirectly from aqueous reactions of $\mathrm{O}_{2}^{-}$. Whereas ${ }^{\circ} \mathrm{OH}$ is a strong and nonselective oxidant, it oxidizes the lipid bilayer of membrane and eventually ruptures the cell surfaces. The ${ }^{1} \mathrm{O}_{2}$ was the main mediator of phototoxicity and irreversibly damaged the treated cells, causing the cell membrane oxidation and degradation. Thus, the growth inhibition in B. subtilis and E. coli occurred owing to the direct action of the $\mathrm{ZnO} / \mathrm{CdS}$ nanocomposites on the cell surfaces. When we observed the cellular morphology of B. subtilis and E. coli under FESEM, we observed the surface perturbation, in agreement with the previous reports [27]. The $\mathrm{ZnO} / \mathrm{CdS}$ nanostructures act on microbial cells by generating ROS on cellular membrane, which virtually oxidizes every cellular component and ruptured the cell wall. Therefore, when observing cellular membrane by SEM, we observed irregular shaped cells with pits and ruptured appearances on surfaces (Figure 4). The surface perturbation in B. subtilis and E. coli agreed with the previous reports [28].

\subsection{Anti-Biofilm}

Biofilm is a severe problem in biomedical sector; the medical implants and indwelling devices are severely affected due to bacterial colonization and biofilm formation. The conventional antibiotic therapies have become ineffective against device-associated biofilm [29]. Thus, to overcome the inherent resistance of bio-

films to antimicrobial agents, we explored $\mathrm{ZnO} / \mathrm{CdS}$ nanocomposite on the biofilm of $P$. aeruginosa. The most distinguishing phenotype of the biofilm mode of 
growth is its intrinsic resistance to antimicrobial treatment and immune response killing [30]. The cells of $P$. aeruginosa in presence of nutrient components of media tend to grow and form biofilm after $36-40 \mathrm{~h}$. We assayed the biofilm by measuring the amount of crystal violet retained by biofilm, because crystal violet has an affinity towards the biofilm. Biofilm retains $100 \%$ crystal violet at $0 \mathrm{~g} / \mathrm{mL}$, however, biofilm retention was reduced to less than $35 \%$ at 50 $\mu \mathrm{g} / \mathrm{mL}$ of $\mathrm{ZnO} / \mathrm{CdS}$ nanocomposites. The formation of biofilm decreased with increase in the concentrations of $\mathrm{ZnO} / \mathrm{CdS}$ nanocomposite. The disruption of biofilm is liable to extend the antimicrobial action of $\mathrm{ZnO} / \mathrm{CdS}$ nanocomposite to the cells protected inside biofilm. Therefore, in order to know the viability of these cells inside biofilm, viable count of cells inside biofilm was performed. As can be seen from Figure 5, the cell viability inside biofilm after exposure
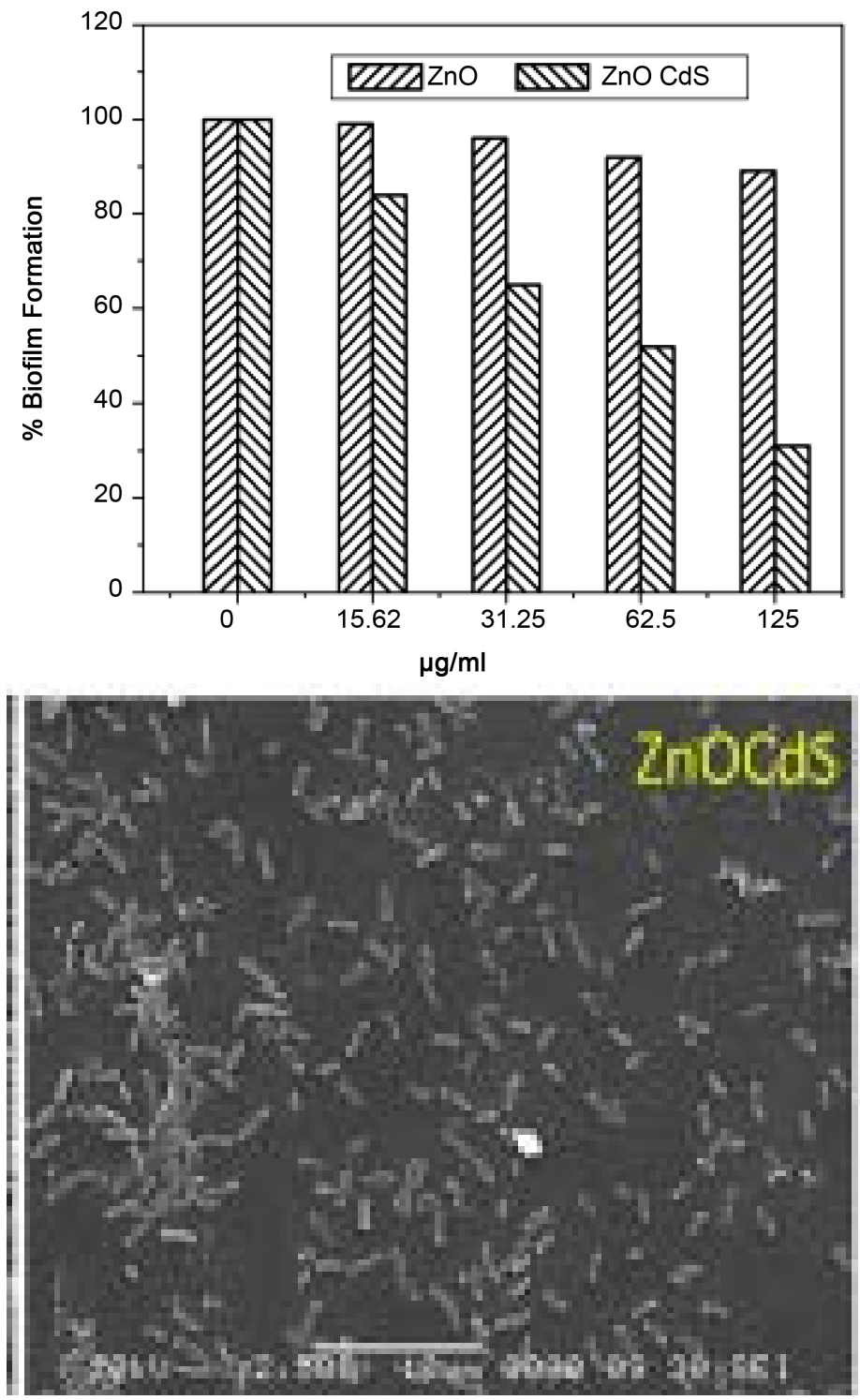

Figure 5. Antibiofilm activity of $\mathrm{ZnO}$ and $\mathrm{ZnO} / \mathrm{CdS}$ on $P$. aeruginosa (upper panel). SEM of biofilm of $P$. aeruginosa. 
$\mathrm{ZnO} / \mathrm{CdS}$ nanocomposite decreased. At $0 \mathrm{~g} / \mathrm{mL}$, cells viability was $100 \%$, however, viability decreased to $40 \%$ at $125 \mu \mathrm{g} / \mathrm{mL}$ of $\mathrm{ZnO} / \mathrm{CdS}$ nanocomposites. The antibiofilm activity in $P$. aeruginosa was also supported by topographical observation of biofilm under FESEM at $50 \mu \mathrm{g} / \mathrm{mL} \mathrm{ZnO} / \mathrm{CdS}$ nanocomposite (Figure 5). Under FESEM, the biofilm of $P$. aeruginosahas been reported as a smooth layer of matrix with an under-covered uniform cell i.e. cells embedded in the polysaccharide's matrix [18], a typical of biofilm structure. However, at 50 $\mu \mathrm{g} / \mathrm{mL} \mathrm{ZnO} / \mathrm{CdS}$ nanocomposite, a truncated biofilm was observed, with cells exposed to outer surfaces (Figure 5). The antibiofilm study is significant because the cells in the biofilm are not viable, and therefore, will not form biofilm. Earlier reports co-relate antibiofilm activity of nanomaterials due to anti-quorum sensing (anti-QS) sensing activity [31] [32]. In present study we rule out the QS mediated antibiofilm activity because our nanostructures also have brought about a reduction in the number of viable cells. We do not rule out the ROS mediated antibiofilm activity in $P$. aeruginosa because ROS species have been reported to carry out the oxidation of polysaccharides, proteins, and lipids biomolecules.

\section{Conclusion}

$\mathrm{ZnO} / \mathrm{CdS}$ nanocomposites are promising applicant for the photocatalytic demolition of bacterial cells. $\mathrm{ZnO} / \mathrm{CdS}$ nanocomposites are effective alternative to organic based drugs. Structural, optical and morphological data confirm the successful synthesis of $\mathrm{ZnO} / \mathrm{CdS}$ nanocomposite. $\mathrm{ZnO} / \mathrm{CdS}$ nanocomposites have shown antimicrobial activity against $B$. subtilis and $E$. coli, and the enhancement in antibacterial property by $\mathrm{ZnO} / \mathrm{CdS}$ nanocomposite was concentration dependent. The ruptured appearances on bacterial cell surfaces indicate cellular membrane damage by $\mathrm{ZnO} / \mathrm{CdS}$ nanocomposites. The decline in the development of biofilm in $P$. aeruginosa in the presence of $\mathrm{ZnO} / \mathrm{CdS}$ nanocomposite shows that it is one of the excellent materials for inhibiting biofilm formations in other clinically pathogenic biofilm forming organisms. $\mathrm{ZnO} / \mathrm{CdS}$ nanocomposites not only showed antibiofilm activity in $P$. aeruginosa, but it also inhibited the microbial population inside the biofilm and eliminates the biofilm forming ability of the microorganisms.

\section{Acknowledgements}

Rajendra Patil acknowledges support from Department Research Grants of Savitribai Phule Pune University, Pune University.

\section{Conflicts of Interest}

The authors declare no conflicts of interest regarding the publication of this paper.

\section{References}

[1] Aslam, B., Wang, W., Arshad, M.I., Khurshid, M., Muzammil, S., Rasool, M.H., Ni- 
sar, M.A., Alvi, R.F., Aslam, M.A., Qamar, M.U., Salamat, M.K.F. and Baloch, Z. (2018) Antibiotic Resistance: A Rundown of a Global Crisis, Infection and Drug Resistance. Infection and Drug Resistance, 11, 1645-1658. https://doi.org/10.2147/IDR.S173867

[2] Li, B. and Webster, T.J. (2018) Bacteria Antibiotic Resistance: New Challenges and Opportunities for Implant-Associated Orthopedic Infections. Journal of Orthopaedic Research: Official Publication of the Orthopaedic Research Society, 36, 22-32. https://doi.org/10.1002/jor.23656

[3] Dias, C., Borges, A., Oliveira, D., Martinez-Murcia, A., Saavedra, M.J. and Simões, M. (2018) Biofilms and Antibiotic Susceptibility of Multidrug-Resistant Bacteria from Wild Animals. PeerJ, 6, e4974. https://doi.org/10.7717/peerj.4974

[4] Baptista, P.V., McCusker, M.P., Carvalho, A., Ferreira, D.A., Mohan, N.M., Martins, M. and Fernandes, A.R. (2018) Nano-Strategies to Fight Multidrug Resistant Bacteria-A Battle of the Titans. Frontiers in Microbiology, 9, 1441. https://doi.org/10.3389/fmicb.2018.01441

[5] Rigo, S., Cai, C., Gunkel-Grabole, G., Maurizi, L., Zhang, X., Xu, J. and Palivan, C.G. (2018) Nanoscience-Based Strategies to Engineer Antimicrobial Surfaces. Advanced Science, 5, Article ID: 1700892. https://doi.org/10.1002/advs.201700892

[6] Baranwal, A., Srivastava, A., Kumar, P., Bajpai, V.K., Maurya, P.K. and Chandra, P. (2018) Prospects of Nanostructure Materials and Their Composites as Antimicrobial Agents. Frontiers in Microbiology, 9, 422. https://doi.org/10.3389/fmicb.2018.00422

[7] Siddiqi, K.S., et al. (2018) Properties of Zinc Oxide Nanoparticles and Their Activity against Microbes. Nanoscale Research Letters, 13, 141.

https://doi.org/10.1186/s11671-018-2532-3

[8] Jiang, J., Pi, J. and Cai, J. (2018) The Advancing of Zinc Oxide Nanoparticles for Biomedical Applications. Bioinorganic Chemistry and Applications, 2018, Article ID: 1062562. https://doi.org/10.1155/2018/1062562

[9] Tiwari, V., Mishra, N., Gadani, K., Solanki, P.S., Shah, N.A. and Tiwari, M. (2018) Mechanism of Anti-Bacterial Activity of Zinc Oxide Nanoparticle against Carbapenem-Resistant Acinetobacter baumannii. Frontiers in Microbiology, 9, 1218. https://doi.org/10.3389/fmicb.2018.01218

[10] Pesci, F.M., Wang, G., Klug, D.R., Li, Y. and Cowan, A.J. (2013) Efficient Suppression of Electron-Hole Recombination in Oxygen-Deficient Hydrogen-Treated $\mathrm{TiO}(2)$ Nanowires for Photoelectrochemical Water Splitting. The Journal of Physical Chemistry. C, Nanomaterials and Interfaces, 117, 25837-25844. https://doi.org/10.1021/jp4099914

[11] Gholap, H., Patil, R., Yadav, P., Banpurkar, A., Ogale, S. and Gade, W. (2013) CdTe- $\mathrm{TiO}_{2}$ Nanocomposite: An Impeder of Bacterial Growth and Biofilm. Nanotechnology, 24, Article ID: 195101. https://doi.org/10.1088/0957-4484/24/19/195101

[12] Chouhan, N., Yeh, C.L., Hu, S.-F., Liu, R.-S., Chang, W.-S. and Chen, K.-H. (2011) Photocatalytic CdSe QDs-Decorated ZnO Nanotubes: An Effective Photoelectrode for Splitting Water. Chemical Communications, 47, 3493-3495. https://doi.org/10.1039/c0cc05548d

[13] Wang, G., Li, Z., Li, M., Chen, C., Lv, S. and Liao, J. (2016) Aqueous Phase Synthesis and Enhanced Field Emission Properties of ZnO-Sulfide Heterojunction Nanowires. Scientific Reports, 6, Article No. 29470. https://doi.org/10.1038/srep29470

[14] An, L., Wang, G., Cheng, Y., Zhao, L., Gao, F. and Cheng, Y. (2015) Synthesis of $\mathrm{CdS} / \mathrm{ZnO}$ Nanocomposite and Its Enhanced Photocatalytic Activity in Degradation 
of Methyl Orange. Russian Journal of Physical Chemistry A, 89, 1878-1883. https://doi.org/10.1134/S0036024415100180

[15] Jana, T.K., Maji, S.K., Pal, A., Maiti, R.P., Dolai, T.K. and Chatterjee, K. (2016) Photocatalytic and Antibacterial Activity of Cadmium Sulphide/Zinc Oxide Nanocomposite with Varied Morphology. Journal of Colloid and Interface Science, 480, 9-16. https://doi.org/10.1016/j.jcis.2016.06.073

[16] Cao, S., Chen, Y., Kang, L., Lin, Z. and Fu, W.-F. (2015) Enhanced Photocatalytic H2-Evolution by Immobilizing CdS Nanocrystals on Ultrathin $\mathrm{Co}_{0.85} \mathrm{Se} / \mathrm{RGO}$-PEI Nanosheets. Journal of Materials Chemistry A, 3, 18711-18717. https://doi.org/10.1039/C5TA04910E

[17] Ozcan, C., Turkay, D. and Yerci, S. (2019) Optical and Electrical Design Guidelines for ZnO/CdS Nanorod-Based CdTe Solar Cells. Optics Express, 27, A339-A351. https://doi.org/10.1364/OE.27.00A339

[18] Gholap, H., Warule, S., Sangshetti, J., Kulkarni, G., Banpurkar, A., Satpute, S. and Patil, R. (2016) Hierarchical Nanostructures of Au@ZnO: Antibacterial and Antibiofilm Agent. Applied Microbiology and Biotechnology, 100, 5849-5858. https://doi.org/10.1007/s00253-016-7391-1

[19] Singh, S., Thiyagarajan, P., Mohan Kant, K., Anita, D., Thirupathiah, S., Rama, N., Tiwari, B., Kottaisamy, M. and Ramachandra Rao, M.S. (2007) Structure, Microstructure and Physical Properties of ZnO Based Materials in Various Forms: Bulk, Thin Film and Nano. Journal of Physics D: Applied Physics, 40, 6312-6327. https://doi.org/10.1088/0022-3727/40/20/S15

[20] Liu, H., Zeng, F., Lin, Y., Wang, G. and Pan, F. (2013) Correlation of Oxygen Vacancy Variations to Band Gap Changes in Epitaxial ZnO Thin Films. Applied Physics Letters, 102, Article ID: 181908. https://doi.org/10.1063/1.4804613

[21] Warule, S.S., Chaudhari, N.S., Shisode, R.T., Desa, K.V., Kale, B.B. and More, M.A. (2015) Decoration of CdS Nanoparticles on 3D Self-Assembled ZnO Nanorods: A Single-Step Process with Enhanced Field Emission Behaviour. CrystEngComm, 17, 140-148. https://doi.org/10.1039/C4CE01738B

[22] Lipovsky, A., Gedanken, A. and Lubart, R. (2013) Visible Light-Induced Antibacterial Activity of Metaloxide Nanoparticles. Photomedicine and Laser Surgery, 31, 526-530. https://doi.org/10.1089/pho.2012.3339

[23] Fu, P.P., Xia, Q., Hwang, H.-M., Ray, P.C. and Yu, H. (2014) Mechanisms of Nanotoxicity: Generation of Reactive Oxygen Species. Journal of Food and Drug Analysis, 22, 64-75. https://doi.org/10.1016/j.jfda.2014.01.005

[24] Fan, W., Sun, Q., Li, Y., Tay, F.R. and Fan, B. (2018) Synergistic Mechanism of $\mathrm{Ag}(+)-\mathrm{Zn}(2+)$ in Anti-Bacterial Activity against Enterococcus faecalis and Its Application against Dentin Infection. Journal of Nanobiotechnology, 16, 10. https://doi.org/10.1186/s12951-018-0336-3

[25] Xie, Y., He, Y., Irwin, P.L., Jin, T. and Shi, X. (2011) Antibacterial Activity and Mechanism of Action of Zinc Oxide Nanoparticles against Campylobacter jejuni. Applied and Environmental Microbiology, 77, 2325-2331. https://doi.org/10.1128/AEM.02149-10

[26] He, W., Kim, H.K., Wamer, W.G., Melka, D., Callahan, J.H. and Yin, J.J. (2014) Photogenerated Charge Carriers and Reactive Oxygen Species in $\mathrm{ZnO} / \mathrm{Au}$ Hybrid Nanostructures with Enhanced Photocatalytic and Antibacterial Activity. Journal of the American Chemical Society, 136, 750-757. https://doi.org/10.1021/ja410800y

[27] Sirelkhatim, A., Mahmud, S., Seeni, A., Kaus, N.H.M., Ann, L.C., Bakhori, S.K.M., Hasan, H. and Mohamad, D.J.N.-M.L. (2015) Review on Zinc Oxide Nanoparticles: 
Antibacterial Activity and Toxicity Mechanism. Nano-Micro Letters, 7, 219-242. https://doi.org/10.1007/s40820-015-0040-x

[28] Ramasamy, M., Das, M., An, S.S. and Yi, D.K. (2014) Role of Surface Modification in Zinc Oxide Nanoparticles and Its Toxicity Assessment toward Human Dermal Fibroblast Cells. International Journal of Nanomedicine, 9, 3707-3718. https://doi.org/10.2147/IJN.S65086

[29] Wu, H., Moser, C., Wang, H.-Z., Høiby, N. and Song, Z.-J. (2014) Strategies for Combating Bacterial Biofilm Infections. International Journal of Oral Science, 7, 1-7. https://doi.org/10.1038/ijos.2014.65

[30] Roy, R., Tiwari, M., Donelli, G. and Tiwari, V. (2018) Strategies for Combating Bacterial Biofilms: A Focus on Anti-Biofilm Agents and Their Mechanisms of Action. Virulence, 9, 522-554. https://doi.org/10.1080/21505594.2017.1313372

[31] Singh, B.R., Singh, B.N., Singh, A., Khan, W., Naqvi, A.H. and Singh, H.B. (2015) Mycofabricated Biosilver Nanoparticles Interrupt Pseudomonas aeruginosa Quorum Sensing Systems. Scientific Reports, 5, Article No. 13719. https://doi.org/10.1038/srep13719

[32] Ali, S.G., Ansari, M.A., Sajid Jamal, Q.M., Khan, H.M., Jalal, M., Ahmad, H. and Mahdi, A.A. (2017) Antiquorum Sensing Activity of Silver Nanoparticles in $P$. aeruginosa: An in Silico Study. In Silico Pharmacology, 5, 12.

https://doi.org/10.1007/s40203-017-0031-3 